\title{
Prologue: Breaking Free from Death
}

\author{
Two fateful forces control us our entire life.

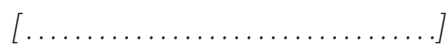 \\ They are death and how other people judge us.? \\ -Fyodor Tyutchev, 1869
}

C6 T'm thinking of Lev Tolstoy now," Yury Olesha (1899-1960) recorded in 1 his notes in December 1959. Tolstoy always loomed large for Olesha, who for years wanted to write a grand novel comparable to Anna Karenina. Olesha, who had cancer, had less than five months to live, and his interest in Tolstoy's final moments was not purely academic:

[Tolstoy] was constantly contemplating death. Let's recall now what death meant to him. He fell ill with pneumonia and, when on the second or third day his condition deteriorated, he began to breathe noisily, frightfully so that his breathing could be heard all over the house. Today this is called Cheyne-Stokes respiration, which is a symptom of fastapproaching death due to paralysis of a person's respiratory center. The name of the symptom is derived from the names of the two physiciansCheyne and Stokes-who first described it. The same symptom was recorded in the medical certificate confirming Stalin's death. Tolstoy also had the same symptom right before he died. Were these moments of Tolstoy's meeting with his death brightly illuminated in his mind?

1 “Аве силы есть-Аве роковые силы, / Всю жизнь свою у них мы поА рукой, / От колыбельных Аней и до могилы,-/ ОАна есть смерть, Аругая-СуА мюАской." Unless otherwise indicated, all translations from Russian are mine, in collaboration with Alexander Burak. 
Did death manifest itself in the way Tolstoy envisaged it all his life? I don't think so. He would have been devoid of any sensations; he simply would have been unaware of what was happening to him. But before these moments, he was still alive, reaching over for his medications. There was nothing in common between Tolstoy's death and the death of Ivan Ilyich, with his saying "Let me pass" [propustite] rather than "Forgive me" [prostite]. There was nothing in common between Tolstoy's own death and the mundane, healthy nonsense that he invented in the course of his constant envisioning of death as [accompanied by] some kind of light, forgetting that, in this context, "light" was a poetic notion and not a physical phenomenon accompanying death. Two physicians-Cheyne and Stokesknew the exact, physiological manifestations of death. They knew, for example, that it was not [the arrival of] some kind of light but a cessation of the activities of the respiratory center, which, in all probability, the dying person would be unaware of. ${ }^{2}$

Was Tolstoy at the moment of his death truly unaware of any physical sensations as Olesha implies in his detached analysis? Does it matter? As Pascal wrote, "It is dangerous to make man too aware that he is on the same level as animals without demonstrating to him his greatness. It is also dangerous to make him too aware of his greatness without showing him his baseness. It is even more dangerous to leave him ignorant of either state, but very helpful to demonstrate both of them to him."3 Pascal's pensée reads as a prophetic summation of Tolstoy's future gigantic accomplishments. If anything, Olesha's analysis attests to Tolstoy's boundless resourcefulness and imagination-qualities that for many years allowed him to transform death's dreadful physicality into an enlightening spiritual experience. Montaigne and Pascal suggested early on that all human activity is driven by the need to divert human beings from thinking about their own finitude. ${ }^{4}$ Olesha's scrutiny of Tolstoy's masterpiece was likely fueled by a similar yearning (whether conscious or subconscious) for distraction. Olesha probably compared Tolstoy's view of death to that of Cheyne and Stokes not for the sake of questioning Tolstoy's acclaimed intuition but for the sake of keeping his own thoughts about his own death at bay.

2 Iurii Olesha, Kniga proshchaniia (Moscow: Vargius, 1999), 433.

3 Blaise Pascal, Pensees and Other Writings, trans. Honor Levi (Oxford: Oxford University Press, 2008), 38. Tolstoy read and admired Pascal.

4 Pascal echoes Montaigne in the section entitled "Diversion," 44. 
Ernest Becker writes, "The knowledge of death is restrictive and conceptual, and animals are spared it. They live and they disappear with the same thoughtlessness: a few minutes of fear, a few seconds of anguish, and it is over. But to live a whole lifetime with the fate of death haunting one's dreams and even the most sun-filled days - that's something else." ${ }^{5}$ Becker draws his conclusions not only from the works of great thinkers like Montaigne, Pascal, Kierkegaard, and Heidegger but also from the findings of psychoanalysts and psychologists, such as William James, Freud, Rank, Adler, and many others who have stood the test of time:

Everything that man does in his symbolic world is an attempt to deny and overcome his grotesque fate. He literally drives himself into a blind obliviousness with social games, psychological tricks, personal preoccupations so far removed from the reality of his situation that they are forms of madness, disguised and dignified madness, shared madness, but madness all the same. "Character-traits," said Sandor Ferenczi ... . "are secret psychoses." 6

In Breaking Free from Death, I analyze how creative people respond to the burden of living with a realization of their inevitable finitude. While there are many insightful books devoted to the nature of creativity, I approach the phenomenon of creativity from another angle. Instead of focusing on creativity as such, I look at the circumstances that make a creative process possible or impossible. What contributes to creative death are not just crippling diseases that make man defenseless in the face of death, not just the arguably universal fear of death, and not just everyday hardships and political persecution but, equally important, the various impositions on the part of outsiders or, conversely, their pliability and helpfulness for the creative process. As Becker points out, the omnipresence of death pushes human beings toward some form of adjustment. I submit that with artists this adjusting process takes different forms, depending on how they manage to negotiate the delicate balance between their own needs and expectations and the needs and expectations of their peers and society at large. The artist needs life to secure his afterlife. Equally, what this afterlife is going to look like depends on the choices he makes and on the ways those choices affect his contemporaries.

5 Ernest Becker, The Denial of Death (New York: Simon \& Shuster, 1997), 27.

6 Ibid. 
After his Dead Souls was hailed as an incisive critique of Tsar Nicholas's Russia, Nikolai Gogol (1809-52), the beneficiary of Nicholas's much-needed financial support, chose to live for the rest of his life in Dante's shadow. Gogol would say that Dead Souls was only the first part of his grand trilogy, that it ought to be compared with Dante's Inferno, and that his very own Purgatory and Paradise-full of positive personalities and life-affirming examples-would follow shortly. In hindsight, Gogol's identification with Dante made him prisoner of that spur-of-the-moment decision and provided all those who wanted to influence and control his creativity with a lot of space for maneuvering. As Simon Karlinsky contends, "In a misguided effort to become the kind of realist writer his contemporaries took him to be, Gogol spent eleven years trying to make himself over into a second-rate Turgenev or Goncharov."7 Karlinsky continues:

While Gogol had no trouble imagining the grotesque and comical aspects of Russian provincial reality in the original Dead Souls, picturing the attractive and constructive sides of this reality was something else.... Gogol's notebooks from that period teem with factual information: the administrative hierarchy, religious customs, forms of economic dealings between landowners and serfs, commerce, methods of jurisprudence, clothing, names of local fish and birds. It is as if Gogol had suddenly become a total stranger to the country he had described with so much assurance in the published portion of Dead Souls. In the introduction to the 1847 edition of the book, Gogol pleaded with his readers to send him corrections of any factual errors his book might contain and suggestions about what he had omitted, as well as descriptions of life in the upper social stratum. "I need to know this class, which is the flower of our people," Gogol wrote. "I cannot publish the latest volumes of my book until I acquire some knowledge of all the aspects of Russian life, at least to the extent I need to know it for my work in progress."

Gogol's reaction to the outside suggestions, good wishes, and expectations was to seek refuge abroad (in Italy) for as long as possible. At the same time, he zealously immersed himself in religious preaching, which, as it turned out, did

7 Simon Karlinsky, The Sexual Labyrinth of Nikolai Gogol (Chicago: University of Chicago Press, 1976), 242.

8 Ibid., 240-41. 
not give Gogol the desired protection against his friends, admirers, and critics. His final act was to depart forever from all those who kept pestering him about a continuation of his novel. "For the rest of my life, I would keep thinking about this greatness-defeated man - a fate so common among Russians - only in his case the destruction came about with a resounding bang," Dostoevsky wrote in 1877. ${ }^{9}$ Was Gogol's identification with Dante doomed from the start? Or did it, in fact, secure him eleven more years of hopeful searching for new forms of literary expression? As I show in part two, Ivan Bunin's identification with Tolstoy turned out to be highly beneficial for the former's well-being and creativity.

Russian writers often feature in narratives devoted to their heroic struggles in adverse political situations to the exclusion of anything else. I am predominantly interested in the variety of factors that constitute the elusive fabric of creativity and creativeness - such as a writer's sources of inspiration, living arrangements, and daily routines, as well as their choice of friends, confidants, and even enemies. As I intend to show, many conflicts in the lives of my subjects arose not from their opposition to the existing political regimes but from their interactions with like-minded and supportive intellectuals, friends, and relatives.

What often looks like a writer's "unfortunate fate" was usually the result of his/her ingenuity and adaptability. Thus, Pushkin was quick to realize the benefits of exile and seclusion in order to become more productive. He was extremely productive during his exile to Crimea, the Caucasus, and his Mikhailovskoe estate. He reproduced these conditions, when he was no longer forced into isolation, during his magnificently prolific first Boldino period (1830) and second Boldino period (1832). Had his fateful duel turned out in his favor, it would have most likely have resulted in another exile as a form of punishment. Chekhov's inexplicable (for the sick person that he was) trip to the island of Sakhalin in 1890 was, perhaps, a Gogolian attempt to free himself from his numerous self-appointed guardians and mentors. Once he became widely successful in the late 1880 s, these people started to demand a grand novel from him, as it was seen as a more respectable genre than short stories or plays. In 1888-89, Chekhov kept promising a novel in his letters to his "well-meaning" advisers, but no matter how hard he tried, he could not reach his goal and felt increasingly uncomfortable at his inability to live up to his mentors' expectations. In many ways, the premature and tragic death of his brother

9 F. M. Dostoevskii, "Podgotovitel'nye materialy k iiul'sko-avgustovskomu 'Dnevniku' 1877 goda," in Polnoe sobranie sochinenii, 30 vols. (Leningrad: Nauka, 1983), 25:250. 
Nikolai in June 1889 was a fateful blessing in disguise, since it offered Chekhov a legitimate reason for discarding his work on the expected novel for the foreseeable future. Chekhov's subsequent trip to Sakhalin (where Chekhov, like Gogol, immersed himself in ethnographic research) was a further step toward sheltering himself from external pressure. After his triumphant return from the island, no one felt that they were in a position to request a lengthy work of literature from him. He had accomplished enough for posterity.

For Yury Olesha, Stalin's oppressive regime provided a plausible and convenient excuse for his meager output during the thirty years following the publication of his highly successful Envy (1927). There is no evidence that he would have written much more had he had a chance to work in a different environment. It is an ironic coincidence that Olesha died in 1960, during Khrushchev's Thaw, with its liberating atmosphere, new freedoms, and new publishing venues. As I have shown elsewhere, Anna Akhmatova ingeniously used her semi-voluntary cohabitation with many difficult lodgers in a large communal apartment as a major excuse for not writing in the 1920s and up until 1938. ${ }^{10}$ That she was astoundingly productive in the very same communal apartment in 1939 did not seem to puzzle her admirers. They saw it as a sign of her superhuman ability to overcome adversity.

"What are you writing these days? What have you got in store for us?" these are the questions that drive Chekhov's fictional writer Boris Trigorin mad. Venedikt Erofeev (1938-90) chose to hide himself from his well-meaning "persecutors" by drinking heavily. This provided him with an excuse for losing his allegedly near-finished works on commuter trains and other means of transportation. In the 1970s before personal computers, such excuses seemed valid enough, while rumors about Erofeev feverishly working on another promising project abounded. ${ }^{11}$ For Erofeev's peers, the stigma of being an alcoholic was less detrimental to his reputation than the stigma of his having a barren imagination. Somehow, the writer's admirers were willing to accept his inability to look after his newly written manuscripts, while at the same time they were not prepared to give him sufficient time and space to nurture his creativity. Instead, they all cheerfully expected an immediate follow-up to his masterpiece Moscow-Petushki (1969).

10 Galina Rylkova, The Archaeology of Anxiety: The Russian Silver Age and Its Legacy (Pittsburgh: University of Pittsburgh Press, 2007), 66-107.

11 On Erofeev in the 1970s, see Elena Ignatova, Obernuvshis' ("Venedikt"), http://www. antho.net/library/ignatova/obernuvshis/01.html. 
Erofeev's predicament is a vivid illustration of how various mishaps enlace artists' relationships with their aficionados. In Art and Artist, Otto Rank reveals that any creative personality must maintain an intricate balance between his personal ambitions and the demands of the society that he belongs to. While an artist may pursue his private agenda, believing that his primary responsibility is only to himself and his art, society may see the artist as a vehicle subordinated to its ideology and agendas, and as a means to collective immortality (i.e., the work of an artist should ultimately immortalize not an individual but his epoch and contemporaries). ${ }^{12}$ Consequently, the work of an artist cannot be a totally private matter, no matter how reclusive a life he/she leads. In his Powers of Two, author and essayist Joshua Shenk focuses on the dyad-the tiny and most viable unit of creativity. His goal is to prove that no one can create in a vacuum. ${ }^{13}$ The less obvious "other" in his chosen pairs is just as important as the celebrated creator, who usually gets all the credit. Here I pursue a broader scope. I look at writers' inner circles, such as family, friends, and associates, as well as at their personal circumstances (e.g., their proximity to death and proclivity for thinking about it).

What makes creative people different from anyone else is that an artist "has to earn his value as a person from his work, which means that his work has to carry the burden of justifying him" and ultimately of "qualifying [him] for immortality." ${ }^{14}$ It is this value that an artist (together with his society) places on his/her work that makes his/her life both unbearable and worth fighting for. In his discussion of ethics, Giorgio Agamben argues that "there is no essence, no historical or spiritual vocation, no biological destiny that humans must enact or realize. This is the only reason why something like an ethics can exist, because it is clear that if humans were or had to be this or that substance, this or that destiny, no ethical experience would be possible - there would be only tasks to be done." 15 Man's destiny is to be "one's own possibility or potentiality, then and only for this reason ... humans have and feel a debt.... The only evil consists instead in the decision to remain in a deficit of existence; or rather (and this is the destiny of morality) to regard potentiality itself, which is the most

12 Otto Rank, Art and Artist: Creative Urge and Personality Development [1932], trans. Charles Francis Atkinson (New York: W. W. Norton, 1989).

13 Joshua Shenk, Powers of Two: Finding the Essence of Innovation in Creative Pairs (Boston: Houghton Mifflin Harcourt, 2014).

14 Becker summarizes Rank's ideas in Denial of Death, 109.

15 Giorgio Agamben, The Coming Community, trans. Michael Hardt (Minneapolis: University of Minnesota Press, 1993), xi. 
proper mode of human existence, as a fault that must always be repressed." 16 Following Agamben, I describe my subjects' strategies to remain true to what they believed in as their potentialities.

In Breaking Free from Death I examine the lives and choices that concrete individuals and-by extrapolation - their literary characters must face in order to preserve their singularity and integrity while attempting to achieve fame, greatness, and success. In the Divine Comedy, Dante famously wrote himself out of his spiritual and creative crisis. Likewise, I see my subjects' literary works as manifestations of their authors' unresolved or worked-through anxieties. To enlist Leon Edel's depiction of literary biography, literary studies are "irrelevant if [they do not] discover the overlap between what the individual did and the life that made this possible." ${ }^{17}$ Everything an artist does is somehow related to his creativity. Victor Shklovsky highlighted this aspect in his description of Tolstoy's fatal departure from Yasnaya Polyana:

He found himself on a new boundary of a new land which he saw but could not enter.

Tolstoy's departure from Yasnaya Polyana was not the flight of an old man into a strange, chilly, damp world.

It was the resolution of an artist to cut himself away from the past, mastering the compassion he felt for his family. ${ }^{18}$

I admire my chosen writers for their creative approaches to their own lives and for their ability to overcome crucial obstacles standing in the way of their achieving greatness.

The book consists of two parts. In part one, "Beginnings and Endings," I concentrate on Chekhov's and Tolstoy's ways of getting out of the critical situations that threatened to end their respective careers at their zenith. Both writers were "perpetual beginners" and shared the same impulse for starting everything anew when faced with writing block or circumstances that were seemingly out of their control. In order to cope, they would rather embark on a new project, cultivate a new frame of mind, create new surroundings, and/or reform their own family. While this might have been natural for a short story

16 Ibid.

17 Leon Edel, "The Art of Biography No. 1," interview by Jeanne McCulloch, Paris Review 98 (Winter 1985), https://www.theparisreview.org/interviews/2844/leon-edel-the-art-ofbiography-no-1-leon-edel.

18 Victor Shklovsky, Lev Tolstoy, trans. Olga Shartse (Moscow: Progress Publishers, 1978), 771. 
writer like Chekhov-after all, each story offered a new beginning-Tolstoy was destined to wear the mantle of a writer of great, long novels and center of Russia's cultural universe. To maintain his pivotal position in Russian literature, Tolstoy had to reinvent himself by adopting new strategies and new sources of inspiration while maintaining his bonds with people who refused to acknowledge this inevitable stage in his evolution. In other words, he had to simultaneously epitomize development, change, and continuity.

Each new beginning, however empowering, means that something else must suffer. Such a predicament does not fail to magnify and intensify beginners' anxieties about both their mortality and permanence. Becker describes "the irony of man's condition" as his "deepest need ... to be free of the anxiety of death and annihilation; but it is life itself which awakens it, and so we must shrink from being fully alive." ${ }^{19}$ I examine the writers' attempts at making death a more manageable (in the case of Chekhov) or more palpable and prominent (in the case of Tolstoy) presence in their lives. The chapter on Uncle Vanya reveals various sources, and kinds, of sustainability that keep talented people afloat. I show what happens when such reservoirs remain unrecognized, untapped, or abused.

In part two, “Transcending Death," I discuss the role of Chekhov's and Tolstoy's texts in other people's confrontations with death and posterity. The chapter on Vsevolod Meyerhold (the theater director and author) examines his ingenious misreading of Chekhov's The Seagull. As a result, Meyerhold got out of the situation that threatened his life and career and went on to invent a new theater. The chapter on Bunin's literary biographies of Tolstoy and Chekhov describes how Bunin used his subjects as vehicles for reducing his fears about his own finitude. The chapter on The Cherry Orchard offers a contemporary reading of Chekhov's last work. The final chapter and the epilogue present a closer look at Chekhov's last days and funeral.

Cumulatively, I hope to show that a productive writer's life (that is, a writer who succeeds in putting his/her thoughts about death and mortality in perspective) requires no less effort and creativity than a true masterpiece.

19 Becker, Denial of Death, 66. 